\title{
Moderate and light cattle grazing effects on Chihuahuan Desert rangelands
}

\author{
JERRY HOLECHEK, DEE GALT, JAMUS JOSEPH, JOSEPH NAVARRO, GODFREY KUMALO, FRANCISCO \\ MOLINAR, AND MILT THOMAS
}

Authors are Professor, Department of Animal and Range Sciences, New Mexico State University, Las Cruces, N.M. 88003; private Range Consultant, 3000 Devandale Drive, Las Cruces, N.M. 88005; Graduate Research Assistants, Department of Animal and Range Sciences, New Mexico State University, Las Cruces, N.M. 88003; Professor, Center for Biological Studies, University of Juarez, Chihuahua, Mexico; and Assistant Professor, Department of Animal and Range Sciences, New Mexico State University, Las Cruces, N.M 88003.

\begin{abstract}
Vegetation changes were evaluated over a 13 year period (1988-2000) on moderately grazed and lightly grazed rangelands in the Chihuahuan Desert of south central New Mexico. During the study period, grazing use of primary forage species averaged 49 and $26 \%$ on moderately and lightly grazed rangelands, respectively. Autumn total grass and black grama (Bouteloua eriopoda Torr.) standing crop were consistently higher on the lightly than moderately grazed rangeland throughout the study. Total grass standing crop declined on the moderately grazed rangeland when the last 3 years of study were compared to the first 3 years (10 versus $124 \mathrm{~kg} \mathrm{ha}^{-1}$ ), but showed no change on the lightly grazed rangeland ( 320 versus $357 \mathrm{~kg} \mathrm{ha}^{-1}$ ). Black grama, the primary perennial grass in the Chihuahuan Desert, increased in autumn standing crop on the lightly grazed rangeland, but decreased on the moderately grazed rangeland. Dropseed (Sporobolus spp.) autumn standing crop decreased on both rangelands during the study. However, this decrease was greater on the moderately grazed rangeland ( $97 \%$ decline) than on the lightly grazed rangeland (67\% decline). Perennial grass survival following a 3-year period of below average precipitation was higher on the lightly grazed $(51 \%)$ than the moderately grazed rangeland $(11 \%)$. Severe grazing intensities on the moderately grazed rangeland during the dry period (1994-1996) appear to explain differences in grass survival between these 2 rangelands. Our study and several others show that light to conservative grazing intensities involving about $25-35 \%$ use of key forage species can promote improvement in rangeland ecological condition in the Chihuahuan Desert, even when accompanied by drought.
\end{abstract}

Key words: Stocking rate, arid lands, livestock, range management

Chihuahuan Desert rangelands in the southern half of New Mexico and north central Mexico support nearly a half million animal units of livestock and numerous species of wildlife. Because of aridity and fragile soils, these rangelands are easily damaged by poorly controlled livestock grazing (Paulsen and Ares 1962, Buffington and Herbel 1965). Better information is

This research was supported by the New Mexico Agr. Exp. Sta., Las Cruces, N.M. 88003 and was part of project 0172944 .

Manuscript accepted 8 Jun. 02.
Resumen

Durante un periodo de 13 años (1988-2000) se evaluaron los cambios de vegetación en pastizales del Desierto Chihuahuense de la región sur central de New Mexico y que fueron apacentados ligeramente y moderadamente. Durante el periodo de estudio la utilización de las principales especies forrajeras promedio de 49 y $26 \%$ para los pastizales con apacentamiento moderado y ligero respectivamente. A través del estudio la biomasa total en pie de los zacates en otoño y la del "Black grama" (Bouteloua eriopoda Torr.) fueron consistentemente mayores en el pastizal apacentado ligeramente que en el apacentado moderadamente. Al comparar los últimos 3 años del estudio con los primeros 3 años se detectó que la biomasa total en pie disminuyo en el pastizal apacentado moderadamente (10 versus $\left.124 \mathrm{~kg} \mathrm{ha}^{-1}\right)$, pero no mostró cambios en el pastizal apacentado ligeramente (320 versus $357 \mathrm{~kg} \mathrm{ha}^{-1}$ ). El "Black grama", el principal zacate perenne del desierto Chihuahuense, aumento su biomasa en pie en otoño en el pastizal apacentado ligeramente, pero disminuyó en el pastizal apacentado moderadamente. Durante el estudio la biomasa en pie del "Dropseed" (Sporobolus spp.) producida en otoño disminuyó en ambos pastizales. Sin embargo, esta disminución fue mayor en el pastizal apacentado moderadamente $(97 \%$ de disminución) que en el apacentado ligeramente (67\% de disminución) La sobrevivencia de los zacates perennes después de un periodo de 3 años por debajo de la precipitación promedio fue mayor en el apacentamiento ligero $(51 \%)$ que en el apacentamiento moderado $(11 \%)$. Intensidades severas de apacentamiento ocurridas durante el periodo seco (1994-1996) en el pastizal apacentado moderadamente parecen explicar las diferencias en la sobrevivencia de los zacates entre estos dos pastizales. Nuestro estudio y algunos otros muestran que intensidades de apacentamiento de ligeras a conservadoras con un 25 - 35\% de uso de las especies forrajeras clave pueden promover el mejoramiento de la condición ecológica del Desierto Chihuahuense, aun cuando se presenten sequías.

needed on plant successional changes on Chihuahuan Desert rangelands under different stocking strategies. About $70 \%$ of the Chihuahuan Desert in southern New Mexico is controlled by the Bureau of Land Management (BLM). Generally, BLM rangelands are managed for multiple uses with a goal of about $50 \%$ use of perennial grasses over long time periods. In some years, grazing use may be lighter and other years heavier depending on annual precipitation. Various studies reviewed by Holechek et al. (1999) have indicated conservative grazing (about 35\% use of 
perennial grasses) through time promotes increased forage productivity and may give higher financial returns than moderate grazing (about $45 \%$ use of perennial grasses).

During the 13-year period from 1988 to 2000 , we evaluated long-term vegetation changes on 2 adjoining Chihuahuan Desert rangelands in southwestern New Mexico with similar soils, climate, and terrain (flat) that were assigned different stocking strategies. One rangeland unit was grazed lightly with the goal of $30 \%$ use of perennial grasses while the other was grazed moderately for $50 \%$ use. Variable stocking rates were applied to both rangelands taking into account changing forage conditions among years. Our objectives were to evaluate trend in forage production, herbaceous cover, brush cover, species composition, and rangeland condition on the 2 rangelands.

This research is a continuation of a long-term study initially reported by Holechek et al. (1994). During the 1982-1990 period, they found forage production increased on the 2 rangelands in our study in response to above average precipitation and conservative grazing use. Our study provides a detailed evaluation of vegetation changes on the 2 rangelands in the 1988-2000 period.

\section{Materials and Methods}

\section{Study Areas}

Our 2 study areas were a lightly grazed site on the New Mexico State University Chihuahuan Desert Rangeland Research Center and an adjoining Bureau of Land Management (BLM) moderately grazed site (32 32' 30" N $106^{\circ} 52^{\prime} 30^{\prime \prime} \mathrm{W}$ ) (Fig. $1)$. Both study areas are approximately 1,300 ha in size. The area is bound by the San Andres Mountains on the east and several isolated mountains on the west. Elevation varies from 1,190 to $1,380 \mathrm{~m}$ with level or gently rolling hills. Soils are primarily shallow, fine sandy loams (Aridisols) of the Simona-Cruces association (Tembo 1990). Topography is relatively flat with all slopes under $5 \%$.

Long-term (1930-2000) average annual precipitation on the Chihuahuan Desert Rangeland Research Center is $23.6 \mathrm{~cm} \mathrm{yr}^{-1}$. Seasonal patterns of precipitation are characterized by small amounts in spring and a peak in late summer (August) with gradually reduced amounts during fall. A smaller peak occurs in early winter (January) (Pieper and Herbel 1982). Total and growing season precipitation were collected
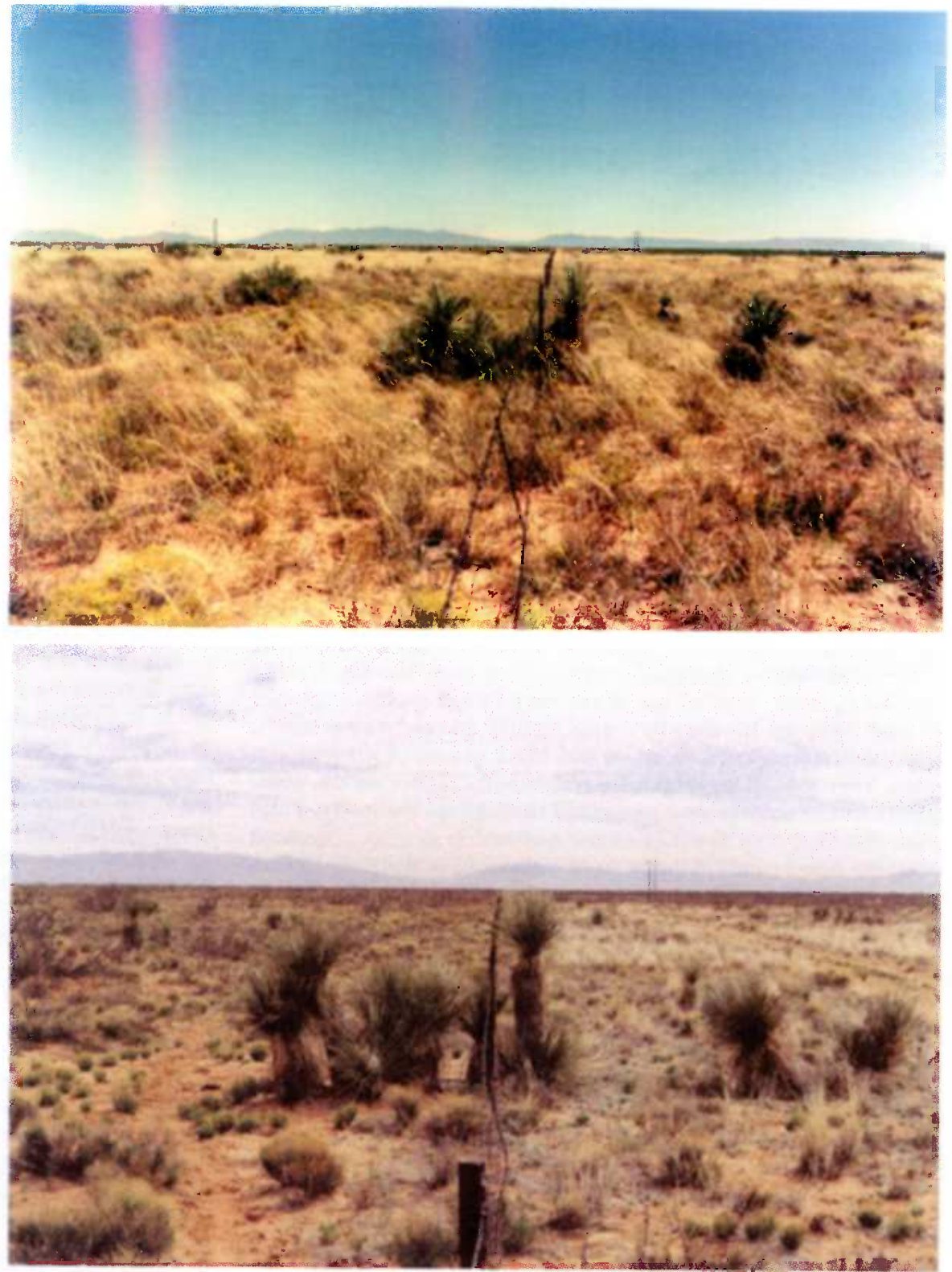

Fig. 1. The fenceline between the moderately grazed range (left) and lightly grazed range (right) in February 1991 (top) and February (2001) bottom.

annually at 10 locations on the Chihuahuan Desert Rangeland Research Center rangeland (Table 1).

Vegetation is classified as Chihuahuan Desert grassland and shrubland (Paulsen and Ares 1962). Most of the grassland areas have been invaded by woody species during the last 100 years (Brown 1950 , Dick-Peddie 1966). The principal vegetation communities are black grama (Bouleoua eriopoda Torr.) grassland, honey mesquite (Prosopis glandulosa Torr.) shrubland, creosotebush (Larrea tridentata Lar.) shrubland, and tarbush (Flourensia cernua D.C.) shrubland (Paulsen and Ares 1962, Pieper and Herbel 1982). Annual forbs include leatherleaf cro- ton (Croton pottsii Lam.), nightshades (Solanum spp.), globemallows (Sphaeralcea spp.), and Russian thistle (Salsola iberica L.). The presence of these forbs is dependent on seasonal precipitation.

A detailed grazing history of the Chihuahuan Desert Rangeland Research Center and BLM study areas is provided by Holechek et al. (1994). Both areas were predominantly black grama grassland with a minor woody component when the Chihuahuan Desert Rangeland Research Center was established in 1927. Zones of degradation were minimized because watering points were widely spaced. Although information is vague, stocking rates on the Chihuahuan Desert Rangeland 


\begin{tabular}{|c|c|c|c|c|c|c|c|c|c|c|c|c|c|c|c|}
\hline & 1988 & 1989 & 1990 & 1991 & 1992 & 1993 & 1994 & 1995 & 1996 & 1997 & 1998 & 1999 & 2000 & $\begin{array}{c}13 \\
\text { Year } \\
\text { Average }\end{array}$ & $\begin{array}{c}\text { Long-term } \\
\text { Average } \\
(1930-2000)\end{array}$ \\
\hline Total precipitation & 30.0 & 19.3 & 21.2 & 38.4 & 39.1 & 25.1 & 17.8 & 17.0 & 20.1 & 29.5 & 20.8 & 28.0 & 27.4 & 25.6 & 23.6 \\
\hline $\begin{array}{l}\text { Growing season } \\
\text { (July, August, September) } \\
\text { Precipitation }\end{array}$ & 17.8 & 10.2 & 19.1 & 18.3 & 12.4 & 13.5 & 5.1 & 10.2 & 12.7 & 14.0 & 9.6 & 15.8 & 3.4 & 12.5 & 12.4 \\
\hline
\end{tabular}

Research Center range averaged 40 ha per animal unit (AU), forage production averaged near $360 \mathrm{~kg} \mathrm{ha}^{-1}$, and forage use averaged about 35\% during the 1930's and 1940's. On the adjacent BLM study site, stocking rates averaged 24 ha $\mathrm{AU}^{-1}$ and grazing use averaged between 60-70\%. A continuous (year-long) grazing system has been used on both study areas from the past to the present. Black grama cover was greatly reduced on both study areas during extended drought in the 1953-1956 period. Herbicide treatments to control brush were applied to approximately $90 \%$ of the Chihuahuan Desert Rangeland Research Center study site in the 1957 to 1964 period (Holechek et al. 1994). Mesquite kill varied from 64 to $93 \%$. The BLM study area received herbicide treatment in 1955 , but no evaluations were made of percent mesquite kill or herbage response.

Grazing on the Chihuahuan Desert Rangeland Research Center study area has been carefully controlled since 1967 when the stocking rate was initially reduced to 67 ha $\mathrm{AU}^{-1}$ (Beck 1978, Holechek 1991, Holechek et al. 1994). During the 24-year period from 1967 to 1991 , forage utilization averaged about $30 \%$. Both rangeland ecological condition and forage production steadily increased. This allowed a gradual stocking rate increase from 67 to $45 \mathrm{ha} \mathrm{AU}^{-1}$ with no increase in forage use or sacrifice in cattle performance (Holechek 1992).

The general goal on the BLM rangeland since 1967 has been to remove about $50 \%$ of the perennial grass production. The stocking rate from the late 1960's to 1981 averaged 42 ha $\mathrm{AU}^{-1}$. In the 1981 to 1990 period, the rancher destocked the range to an average rate of 72 ha $\mathrm{AU}^{-1}$. This management change and above average precipitation resulted in a major increase in forage production and ecological condition (Holechek et al. 1994).

\section{Procedures}

Eight permanent transects (each $6.2 \mathrm{~km}$ in length) spaced 500-m apart were located across each study site (CDRRC and
BLM) to evaluate vegetation canopy cover and standing crop. During the autumn of 1988, 1989, 1990, 1998, 1999, and 2000 incremental measurements of herbaceous foliar cover were taken seasonally along each transect using a modification (Holechek and Stephenson 1983) of the line intercept procedure outlined by Canfield (1941). At 100-m intervals, a 1$\mathrm{m}$ rod incremented at $1-\mathrm{mm}$ intervals was placed perpendicular to the transect and percent foliar cover was recorded by species. Each transect consisted of 64 sampling points. Three detailed measurements of shrub foliar cover were made at $2-\mathrm{km}$ intervals along each transect using $40 \times 2-m$ belt transects (Canfield 1941). These belt transects covered an area of 240- $\mathrm{m}^{2}$ per transect.

Above ground standing crop $\left(\mathrm{kg} \mathrm{ha}^{-1}\right)$ was sampled at the end of the summer growing season (October) from 1988 to 2000. Vegetation was clipped at ground level from 10 systematically located quadrats $(0.5 \times 1.0-\mathrm{m})$ placed at approximately $600-\mathrm{m}$ intervals along each of the $6.2-\mathrm{km}$ transects. Vegetation was hand separated by species in the field, oven dried at $60^{\circ} \mathrm{C}$ for 72 hours, and weighed. Only current-year's growth was measured. Livestock grazing was suspended on the BLM study area from 1 May 1998 to 1 November 1999 and during the growing season (1 July through 30 September) in 2000. This allowed us to evaluate herbage standing crop in the autumn on the BLM rangeland during the last 3 years of study without herbage removal by livestock during the growing season. Because the Chihuahuan Desert Rangeland Research Center rangeland was continuously (yearlong) grazed, autumn current-year standing crop of forage underestimated ungrazed forage production. Forage use levels were light to conservative on both rangelands in the 1988-1990 period. Therefore, we consider autumn currentyear growth to be a reasonable estimate of baseline herbage production. We made no adjustments for utilization.
Late June of each year was used to evaluate grazing intensity because it is the end of the forage cycle prior to new growth of perennial grasses which usually occurs in July (Paulsen and Ares 1962). Grazing intensity was evaluated on each study area using procedures of Anderson and Currier (1973) as modified by Holechek and Galt (2000). These procedures involved assessing grazing intensity on each study area through a combination of perennial grass stubble heights and ungrazed residual biomass of forage plants. Four permanent key areas were systematically established within each study area for these assessments. These key areas were selected by dividing each pasture into 4 equal parts and then locating the key area near the center of each part. All key areas were 1.3 to $1.8 \mathrm{~km}$ from water.

In October 1999, the percentages of live and dead perennial grasses were evaluated on all transects. The procedure involved recording the nearest plant at $200-\mathrm{m}$ intervals along transects as live or dead based on the presence or absence of live above ground biomass. Dead plants were characterized by all blackish above ground biomass while presence of green or yellow above ground biomass characterized living plants.

Rangeland ecological condition scores were calculated from current USDA Natural Resources Conservation Service site guides for New Mexico (shallow sandy site) using the Dyksterhuis (1949) procedure. Relative percent composition of autumn current-year standing herbage on the Chihuahuan Desert Rangeland Research Center and BLM rangelands was used to calculate rangeland ecological condition scores for each year of study (1988-2000).

A repeated measures analysis of variance using the mixed model procedure of SAS (Littell et al. 1996) was used to compare autumn current-year total standing herbage, total grass standing herbage, black grama standing herbage and ecological scores across stocking strategies (2) and years (13). Transects were used as 
replications ( 8 per stocking strategy). Autumn herbaceous standing crop, standing crop relative composition, vegetation foliar cover, and foliar cover relative composition were compared on the lightly grazed and moderately grazed rangelands using data pooled across the first 3 years and the last 3 years of study. A randomized factorial analysis of variance was used with the 2 grazing treatments (light and moderate) and the 2 time periods (1988-1990, 1998-2000) as factors and transects (8 per stocking strategy) as replications. In an analysis of grazing experiments, Holechek et al. (1999) found data pooled across the first and last 3 years of study gave the most meaningful comparisons of long-term vegetation changes. This was because ecological condition and forage production were often not equivalent across grazing treatments at study initiation as in our case. The least significant difference mean separation procedure was used to compare means if analysis of variance indicated a significant $(\mathrm{P}<0.05)$ difference (Steel and Torrie 1980). Comparisons of percentage of live plants between the Chihuahuan Desert Rangeland Research Center and BLM rangelands in 1999 were made using the standard t-test with the 8 transects in each treatment as replicates.

\section{Results and Discussion}

A comparative summary of stocking rate, forage utilization, vegetation standing crop, and rangeland ecological scores on the lightly and moderately grazed rangelands during the 13 year study period is given in Table 2. Stocking rate data in Table 2 are based on the forage cycle year starting 1 July (beginning of forage growth) rather than on the calendar year. This coordinates vegetation standing crop data collected in October with forage utilization data collected the following June.

Over the 13 year study period, total annual precipitation averaged $109 \%$ of the long-term average $\left(23.6 \mathrm{~cm} \mathrm{yr}^{-1}\right)$ (Table 1). During the first 6 years of study, annual precipitation averaged $122 \%$ of the long-term average. However, during the last 7 years, total annual precipitation was $97 \%$ of the long-term average. Drought occurred in 1994. Major stocking rate adjustments were made on both rangelands in response to changing precipitation and forage conditions (Table 2). The general approach on the lightly grazed rangeland was to stock at $70 \%$ of grazing capacity in years of above average to near average growing season precipitation and to destock under conditions of severe drought. Some minor adjustments were made in cattle numbers in the late autumn of each year. If at any time average stubble height of black grama dropped below $5.5 \mathrm{~cm}$, the pasture would be completely destocked for at least 1 growing season. This occurred in late July 1994 and the pasture was immediately destocked. Restocking was not initiated until January 1997 because of poor forage growth in 1996 (Table 2).

On the moderately grazed rangeland, the approach was to stock at grazing capacity (230 animal unit years) unless excessive grazing (over $55 \%$ use of forage) was observed at the end of the forage cycle (June) for 2 consecutive years. If this condition was met, then the stocking rate would be reduced for at least 1 growing season. Recent precipitation conditions and forage availability in the pasture were also used in stocking rate decisions. If forage became severely depleted, complete destocking was an option. Major stocking rate reductions were made in 1994, 1995, 1998, 1999, and 2000 on the moderately grazed rangeland (Table 2).

Total vegetation, total grass, and black grama standing crop differed $(\mathrm{P}<0.05)$ among stocking strategies and years (Table 2). Interactions between stocking strategies and years were significant $(\mathrm{P}<$

Table 2. Stocking rate, forage use, forage production, and rangeland ecological condition scores for the lightly grazed and moderately grazed rangelands from 1988-2000.

\begin{tabular}{|c|c|c|c|c|c|c|c|c|c|c|c|c|c|}
\hline & $88 / 89$ & $89 / 90$ & 90/91 & $91 / 92$ & $92 / 93$ & 93/94 & 94/95 & 95/96 & $96 / 97$ & $97 / 98$ & $98 / 99$ & $99 / 00$ & $00 / 01$ \\
\hline \multicolumn{14}{|c|}{ Lightly Grazed Rangeland } \\
\hline Stocking rate (ha $\left.\mathrm{AUY}^{-1}\right)^{1}$ & 49 & 49 & 49 & 44 & 40 & 50 & 320 & 0 & 210 & 48 & 42 & 40 & 61 \\
\hline Forage utilization $(\%)^{2}$ & 33 & 28 & 33 & 22 & 18 & 33 & 50 & 0 & 10 & 33 & 38 & 18 & 31 \\
\hline $\begin{array}{l}\text { Autumn vegetation } \\
\text { standing crop }\left(\mathrm{kg} \mathrm{ha}^{-1}\right)^{3}\end{array}$ & $527^{\mathrm{cd}}$ & $335^{\mathrm{e}}$ & $414^{d}$ & $716^{\mathrm{b}}$ & $1006^{\mathrm{a}}$ & $281^{\mathrm{ef}}$ & $11^{\mathrm{h}}$ & $150^{\mathrm{g}}$ & $255^{\mathrm{f}}$ & $579^{\mathrm{c}}$ & $457^{\mathrm{d}}$ & $559^{\mathrm{c}}$ & $396^{\mathrm{de}}$ \\
\hline Autumn grass standing & & & & & & & & & & & & & \\
\hline Crop $\left(\mathrm{kg} \mathrm{ha}^{-1}\right)^{3}$ & $452^{\mathrm{b}}$ & $270^{\mathrm{cd}}$ & $349^{c}$ & $554^{\mathrm{b}}$ & $842^{\mathrm{a}}$ & $225^{\mathrm{d}}$ & $7^{e}$ & $57^{\mathrm{e}}$ & $92^{\mathrm{e}}$ & $301^{\mathrm{cd}}$ & $305^{\mathrm{cd}}$ & $403^{\mathrm{bc}}$ & $252^{\mathrm{d}}$ \\
\hline $\begin{array}{l}\text { Autumn black grama } \\
\text { standing crop }\left(\mathrm{kg} \mathrm{ha}^{-1}\right)^{3}\end{array}$ & $95^{\mathrm{ef}}$ & $68^{g}$ & $59^{g}$ & $119^{d}$ & $380^{\mathrm{a}}$ & $86^{\mathrm{fg}}$ & $5^{i}$ & $48^{\mathrm{h}}$ & $66^{\mathrm{g}}$ & $169^{\mathrm{cd}}$ & $120^{\mathrm{d}}$ & $222^{\mathrm{b}}$ & $115^{\mathrm{de}}$ \\
\hline $\begin{array}{l}\text { Rangeland ecological } \\
\text { condition score }\end{array}$ & $62^{\mathrm{bc}}$ & $57^{\mathrm{c}}$ & $57^{\mathrm{c}}$ & $48^{\mathrm{cd}}$ & $59^{\mathrm{c}}$ & $53^{\mathrm{c}}$ & $56^{\mathrm{c}}$ & $64^{\mathrm{b}}$ & $81^{\mathrm{a}}$ & $72^{b}$ & $68^{\mathrm{b}}$ & $88^{\mathrm{a}}$ & $74^{\mathrm{ab}}$ \\
\hline \multicolumn{14}{|c|}{ Moderately Grazed Rangeland } \\
\hline Stocking rate (ha $\left.\mathrm{AUY}^{-1}\right)^{1}$ & 83 & 61 & 46 & 47 & 47 & 47 & 71 & 98 & 47 & 47 & 282 & 304 & 142 \\
\hline Forage utilization $(\%)^{2}$ & 21 & 31 & 38 & 33 & 30 & 48 & 60 & 75 & 80 & 75 & 85 & 20 & 45 \\
\hline $\begin{array}{l}\text { Autumn vegetation } \\
\text { standing crop }\left(\mathrm{kg} \mathrm{ha}^{-1}\right)^{3}\end{array}$ & $229^{b}$ & $227^{\mathrm{b}}$ & $420^{\mathrm{a}}$ & $405^{\mathrm{a}}$ & $500^{\mathrm{a}}$ & $210^{\mathrm{b}}$ & $45^{\mathrm{de}}$ & $22^{\mathrm{e}}$ & $78^{\mathrm{d}}$ & $160^{\mathrm{c}}$ & $134^{\text {cd }}$ & $260^{b}$ & $186^{\mathrm{bc}}$ \\
\hline $\begin{array}{l}\text { Autumn grass } \\
\text { standing crop }\left(\mathrm{kg} \mathrm{ha}^{-1}\right)^{3}\end{array}$ & $104^{\mathrm{c}}$ & $108^{\mathrm{c}}$ & $159^{\mathrm{b}}$ & $201^{\mathrm{ab}}$ & $251^{\mathrm{b}}$ & $140^{\mathrm{bc}}$ & $13^{\mathrm{d}}$ & $3^{\mathrm{d}}$ & $18^{\mathrm{d}}$ & $12^{\mathrm{d}}$ & $2^{d}$ & $8^{\mathrm{d}}$ & $20^{\mathrm{d}}$ \\
\hline $\begin{array}{l}\text { Autumn black grama } \\
\text { standing crop }\left(\mathrm{kg} \mathrm{ha}^{-1}\right)^{3}\end{array}$ & $2^{c}$ & $34^{\mathrm{ab}}$ & $2^{c}$ & $38^{\mathrm{a}}$ & $49^{\mathrm{a}}$ & $20^{\mathrm{b}}$ & $<1^{\mathrm{c}}$ & $<1^{\mathrm{c}}$ & $3^{\mathrm{c}}$ & $<1^{\mathrm{c}}$ & $<1^{\mathrm{c}}$ & $<1^{\mathrm{c}}$ & $2^{\mathrm{c}}$ \\
\hline $\begin{array}{l}\text { Rangeland ecological } \\
\text { condition score }\end{array}$ & $40^{\mathrm{ab}}$ & $48^{\mathrm{a}}$ & $31^{\mathrm{b}}$ & $34^{\mathrm{b}}$ & $39^{\mathrm{b}}$ & $40^{\mathrm{ab}}$ & $36^{\mathrm{b}}$ & $30^{\mathrm{bc}}$ & $26^{\mathrm{c}}$ & $22^{\mathrm{cd}}$ & $10^{\mathrm{e}}$ & $17^{\mathrm{de}}$ & $21^{\mathrm{cd}}$ \\
\hline
\end{tabular}

${ }^{1}$ Stocking rate is for beginning of growing season (July 1) to end of dormancy the following year (June 30).

${ }^{2}$ Estimated in June of following year using procedures of Holechek and Galt (2000).

${ }^{3}$ Current-years growth unadjusted for grazing use.

a-iMeans within rows with different letters differ $(\mathrm{P}<0.05)$. 
Table 3. Average autumn herbaceous standing crop $\left(\mathrm{kg} \mathrm{ha}^{-1}\right)$ and relative herbaceous composition (\%) on lightly grazed (LG) and moderately grazed (MG) Chihuahuan Desert rangelands in south central New Mexico for the 1988-1990 and 1998-2000 periods.

\begin{tabular}{|c|c|c|c|c|c|c|c|c|}
\hline \multirow{4}{*}{ Species or group } & \multicolumn{4}{|c|}{ Autumn Standing Crop } & \multicolumn{4}{|c|}{ Standing Crop Relative Composition } \\
\hline & \multicolumn{2}{|c|}{ LG } & \multicolumn{2}{|c|}{ MG } & \multicolumn{2}{|c|}{ LG } & \multicolumn{2}{|c|}{ MG } \\
\hline & $88-90$ & $98-00$ & $88-90$ & $98-00$ & $88-90$ & $98-00$ & $88-90$ & $98-00$ \\
\hline & $\ldots$ & $\cdots(\mathrm{kg} \mathrm{h}$ & $\left.a^{-1}\right) \ldots$ & $\ldots$ & $-\cdots$ & $\ldots$ & - & $\ldots$ \\
\hline Aristida spp. & $60^{\mathrm{a}}$ & $45^{\mathrm{b}}$ & $13^{\mathrm{c}}$ & $2^{\mathrm{d}}$ & $14^{\mathrm{a}}$ & $10^{\mathrm{a}}$ & $4^{b}$ & $1^{\mathrm{b}}$ \\
\hline Bouteloua eriopoda & $74^{\mathrm{b}}$ & $152^{\mathrm{a}}$ & $13^{\mathrm{c}}$ & $1^{\mathrm{d}}$ & $17^{\mathrm{b}}$ & $32^{\mathrm{a}}$ & $4 c$ & $<1^{\mathrm{d}}$ \\
\hline Erioneuron pulchellum & $4^{\mathrm{b}}$ & $t^{b}$ & $21^{\mathrm{a}}$ & $3^{\mathrm{b}}$ & $1^{\mathrm{a}}$ & $<1^{\mathrm{a}}$ & $7^{\mathrm{a}}$ & $2^{\mathrm{b}}$ \\
\hline Muhlenbergia porteri & $5^{\mathrm{a}}$ & $\mathrm{t}^{\mathrm{a}}$ & $2^{\mathrm{a}}$ & 1 & $1^{\mathrm{a}}$ & $<1^{\mathrm{a}}$ & $1^{\mathrm{a}}$ & $<1^{\mathrm{a}}$ \\
\hline Sporobolus spp. & $169^{\mathrm{a}}$ & $56^{\mathrm{b}}$ & $62^{\mathrm{b}}$ & $3 c$ & $40^{\mathrm{a}}$ & $12^{\mathrm{c}}$ & $21^{\mathrm{b}}$ & $2^{\mathrm{d}}$ \\
\hline Other grasses & $44^{\mathrm{a}}$ & $66^{\mathrm{a}}$ & $13^{\mathrm{b}}$ & $t^{c}$ & $10^{\mathrm{a}}$ & $14^{\mathrm{a}}$ & $4^{b}$ & $<1^{\mathrm{b}}$ \\
\hline Total grasses & $357^{\mathrm{a}}$ & $320^{\mathrm{a}}$ & $124^{\mathrm{b}}$ & $10^{\mathrm{c}}$ & $84^{\mathrm{a}}$ & $68^{\mathrm{b}}$ & $42^{\mathrm{c}}$ & $5^{\mathrm{d}}$ \\
\hline Total forbs & $14^{\mathrm{c}}$ & $73^{\mathrm{a}}$ & $12^{\mathrm{c}}$ & $40^{\mathrm{b}}$ & $3^{c}$ & $15^{\mathrm{b}}$ & $4^{\mathrm{c}}$ & $21^{\mathrm{a}}$ \\
\hline Gutierrezia sarothrae & $54^{\mathrm{b}}$ & $77^{\mathrm{b}}$ & $157^{\mathrm{a}}$ & $143^{\mathrm{a}}$ & $13^{\mathrm{c}}$ & $16^{\mathrm{c}}$ & $54^{\mathrm{b}}$ & $74^{\mathrm{a}}$ \\
\hline Total vegetation & $425^{\mathrm{a}}$ & $471^{\mathrm{a}}$ & $292^{\mathrm{b}}$ & $193^{\mathrm{c}}$ & 100 & 100 & 100 & 100 \\
\hline
\end{tabular}

Data were pooled across the first 3 years and last 3 years of study for trend comparisons as suggested by Holechek et $\mathrm{al}_{\mathrm{a}}$ (1999).

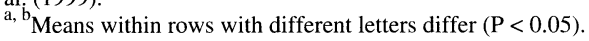

$\mathrm{t}=$ trace

$0.05)$. We will focus our discussion on standing crop trends over time for each stocking strategy concentrating on comparisons between the first and last 3 years of the study (Table 3 ).

Standing crop of total vegetation and total grasses showed no change $(\mathrm{P}>0.05)$ on the lightly grazed rangeland, but declined $(\mathrm{P}<0.05)$ on the moderately grazed rangeland when the last 3 years were compared to the first 3 years of the study (Table 3 ). Black grama standing crop increased on the lightly grazed rangeland, but decreased on the moderately grazed rangeland during the study period. Black grama is the primary decreaser perennial grass in the Chihuahuan Desert (Canfield 1939, Paulsen and Ares 1962). Dropseed (Sporobolus spp.) standing crop decreased $(\mathrm{P}<0.05)$ on both rangelands. We attribute this decrease to below average precipitation in the 1994-1996 period. Dropseeds are less drought tolerant than black grama (Campbell 1929, Herbel and

Table 4. Average autumn vegetation foliar cover (\%) and relative composition on lightly grazed (LG) and moderately grazed (MG) Chihuahuan Desert rangelands in south central New Mexico for the 1988-1990 and 1998-2000 periods.

\begin{tabular}{|c|c|c|c|c|c|c|c|c|}
\hline \multirow{3}{*}{ Species or group } & \multicolumn{4}{|c|}{ Vegetation Foliar Cover } & \multicolumn{4}{|c|}{ Relative Foliar Vegetation Composition } \\
\hline & \multicolumn{2}{|c|}{ LG } & \multicolumn{2}{|c|}{$\overline{M G}$} & \multicolumn{2}{|c|}{ LG } & \multicolumn{2}{|c|}{ MG } \\
\hline & $88-90$ & $98-00$ & $88-90$ & $98-00$ & $88-90$ & $98-00$ & $88-90$ & $98-00$ \\
\hline Aristida spp. & $0.4^{\mathrm{a}}$ & $0.3^{\mathrm{a}}$ & $0.2^{\mathrm{a}}$ & $0.2^{\mathrm{a}}$ & $4^{a}$ & $2^{\mathrm{a}}$ & $1^{\mathrm{a}}$ & $1^{\mathrm{a}}$ \\
\hline Bouteloua eriopoda & $0.4^{\mathrm{a}}$ & $0.6^{\mathrm{a}}$ & $0.1^{\mathrm{b}}$ & $t^{b}$ & $4^{\mathrm{a}}$ & $5^{\mathrm{a}}$ & $<1^{\mathrm{a}}$ & $<1^{\mathrm{a}}$ \\
\hline Erioneuron pulchellum & $0.1^{\mathrm{a}}$ & $0.2^{\mathrm{a}}$ & $0.2^{\mathrm{a}}$ & $0.2^{\mathrm{a}}$ & $1^{\mathrm{a}}$ & $2^{\mathrm{a}}$ & $1^{\mathrm{a}}$ & $1^{\mathrm{a}}$ \\
\hline Sporobolus spp. & $1.4^{\mathrm{a}}$ & $0.4^{\mathrm{c}}$ & $0.9^{\mathrm{ab}}$ & $t^{c}$ & $13^{\mathrm{a}}$ & $3^{\mathrm{b}}$ & $4^{\mathrm{b}}$ & $<1^{\mathrm{b}}$ \\
\hline Total grasses & $2.9^{\mathrm{a}}$ & $2.2^{\mathrm{a}}$ & $1.6^{\mathrm{b}}$ & $0.4^{\mathrm{c}}$ & $26^{\mathrm{a}}$ & $17^{\mathrm{b}}$ & $7^{\mathrm{c}}$ & $2^{d}$ \\
\hline Croton pottsii & $0.3^{\mathrm{a}}$ & $0.2^{\mathrm{a}}$ & ta & $t^{\mathrm{a}}$ & $2^{\mathrm{a}}$ & $1^{\mathrm{a}}$ & $<1^{\mathrm{a}}$ & $<1^{\mathrm{a}}$ \\
\hline Total forbs & $0.4^{\mathrm{a}}$ & $0.4^{\mathrm{a}}$ & $0.2^{\mathrm{c}}$ & $0.5^{\mathrm{a}}$ & $4^{a}$ & $3^{\mathrm{a}}$ & $1^{\mathrm{a}}$ & $2^{a}$ \\
\hline Gutierrezia sarothrae & $1.3^{\mathrm{b}}$ & $2.0^{\mathrm{b}}$ & $6.8^{\mathrm{a}}$ & $8.4^{\mathrm{a}}$ & $12^{\mathrm{b}}$ & $16^{\mathrm{b}}$ & $31^{\mathrm{a}}$ & $34^{\mathrm{a}}$ \\
\hline Ephedra spp. & $0.2^{\mathrm{a}}$ & $0.2^{\mathrm{a}}$ & $0.3^{\mathrm{a}}$ & $0.3^{\mathrm{a}}$ & $2^{\mathrm{a}}$ & $2^{\mathrm{a}}$ & $1^{\mathrm{a}}$ & $1^{\mathrm{a}}$ \\
\hline Yucca elata & $1.2^{\mathrm{a}}$ & $1.3^{\mathrm{a}}$ & $0.7^{\mathrm{a}}$ & $0.7^{\mathrm{a}}$ & $11^{\mathrm{a}}$ & $10^{\mathrm{a}}$ & $3^{\mathrm{b}}$ & $3^{\mathrm{b}}$ \\
\hline Acacia constricta & $0.6^{\mathrm{b}}$ & $0.6^{\mathrm{b}}$ & $1.3^{\mathrm{a}}$ & $1.5^{\mathrm{a}}$ & $5^{\mathrm{a}}$ & $5^{\mathrm{a}}$ & $6^{\mathrm{a}}$ & $6^{\mathrm{a}}$ \\
\hline Prosopis glandulosa & $4.5^{\mathrm{b}}$ & $6.2^{\mathrm{b}}$ & $11.2^{\mathrm{a}}$ & $12.6^{\mathrm{a}}$ & $41^{\mathrm{a}}$ & $48^{\mathrm{a}}$ & $51^{\mathrm{a}}$ & $52^{\mathrm{a}}$ \\
\hline Total shrub cover & $6.5^{\mathrm{b}}$ & $8.3^{\mathrm{b}}$ & $13.5^{\mathrm{a}}$ & $15.1^{\mathrm{a}}$ & $59^{\mathrm{a}}$ & $64^{\mathrm{a}}$ & $61^{\mathrm{a}}$ & $62^{\mathrm{a}}$ \\
\hline Total vegetation cover & $11.1^{\mathrm{b}}$ & $12.9^{\mathrm{b}}$ & $22.0^{\mathrm{a}}$ & $24.4^{\mathrm{a}}$ & 100 & 100 & 100 & 100 \\
\hline
\end{tabular}

Data were pooled across the first 3 years and last 3 years of study for trend comparisons as suggested by Holechek et a., (1999).

a,b Means within rows with different letters differ $(\mathrm{P}<0.05)$.

$\mathrm{t}=$ trace

Gibbens 1996). Total forb standing crop increased $(\mathrm{P}<0.05)$ on both rangelands in 1998-2000 compared to 1988-1990. Forbs in the Chihuahuan Desert are responsive to winter-spring precipitation. Winter-spring precipitation was higher in 1998-2000 than 1988-1990.

Broom snakeweed (Gutierrizea sarothrae Pursh), the primary poisonous plant found on both rangelands, showed no change $(\mathrm{P}>0.05)$ in autumn standing crop on either rangeland when the last and first 3 years of study were compared (Table 3). Broom snakeweed is a shortlived, cyclic half-shrub that can cause abortion in livestock and has severely depressed productivity of perennial grasses on New Mexico rangelands (McDaniel et al. 1993). Populations of broom snakeweed are closely related to climatic conditions (Pieper and McDaniel 1990). Above normal autumn through spring precipitation favors broom snakeweed establishment. Broom snakeweed standing crop levels averaged nearly twice as high $(\mathrm{P}<$ 0.05 ) on the moderately grazed as on the lightly grazed rangeland.

Total grass, total forb, and black grama foliar cover averaged higher $(\mathrm{P}<0.05)$ on the lightly grazed than the moderately grazed rangeland (Table 4). However, total shrub cover was higher $(\mathrm{P}<0.05)$ on the moderately grazed rangeland. Most canopy cover components had significant interactions $(\mathrm{P}<0.05)$ between stocking strategy and time period.

Generally, vegetation foliar cover (Table 4) showed the same trends as autumn standing crop for primary herbaceous components with a few exceptions. We cannot explain why total autumn standing crop of forbs increased $(\mathrm{P}<0.05)$ between 1988-1990 and 1998-2000, but foliar cover showed no change $(\mathrm{P}>0.05)$. We believe this is probably a sampling aberration.

Total shrub and honey mesquite foliar cover showed no changes $(\mathrm{P}>0.05)$ during the period of study on either rangeland. Honey mesquite canopy cover on the lightly grazed range was only half $(\mathrm{P}<$ $0.05)$ that on the moderately grazed rangeland. This is explained in part by more intensive control of mesquite with herbicides on the lightly grazed rangeland prior to the initiation of our study.

Both herbaceous standing crop and foliar cover showed major changes $(\mathrm{P}<$ 0.05 ) in relative vegetation composition when the last and first 3 years of the study were compared (Tables 3 and 4). They were consistent in showing a shift to lower $(\mathrm{P}<0.05)$ total grass and dropseed com- 
ponents on both rangelands and a higher forb component on the moderately grazed rangeland.

Rangeland ecological scores, based on the USDA-NRCS method and current New Mexico range site guides, averaged higher $(\mathrm{P}<0.05)$ on the lightly than moderately grazed rangeland (Table 1). They showed an upward trend $(\mathrm{P}<0.05)$ on the lightly grazed rangeland, but a downward trend $(\mathrm{P}<0.05)$ on the moderately grazed rangeland (Table 2). Rangeland ecological condition scores on both rangelands showed considerable fluctuation among years (Table 2).

We believe our study provides support for the model of Dyksterhuis (1949) regarding rangeland vegetation responses to grazing and climate. However, we cannot reject the state-and-transition model of Westoby et al. (1989). They are not competing models. Both high mesquite foliar cover $(13 \%)$ and lack of perennial grasses make it doubtful that meaningful improvement can occur in ecological condition on the moderately grazed rangeland through grazing management alone (Herbel et al. 1983). Mesquite control will be needed to restore this rangeland to a healthy condition as defined by the United States Department of Interior (2000).

Perennial grass plant survival percentages were higher $(\mathrm{P}<0.05)$ for all 3 grasses [black grama, dropseeds, and threeawns (Aristida spp.)] evaluated on the lightly compared to the moderately grazed rangeland (Table 5). Most perennial grass mor-

Table 5. Percentages of live perennial grass plants on long-term lightly grazed (LG) and long-term moderately grazed (MG) Chihuahuan Desert rangelands in south central New Mexico in Autumn 1999.

\begin{tabular}{lcc}
\hline \hline & LG & MG \\
\hline Grass species & - - (\% live plants) - - \\
Bouteloua eriopoda & $80^{\mathrm{a}}$ & $10^{\mathrm{b}}$ \\
Sporobolus spp. & $23^{\mathrm{a}}$ & $5^{\mathrm{b}}$ \\
Aristida spp. & $67^{\mathrm{a}}$ & $12^{\mathrm{b}}$ \\
Other grasses & $35 \mathrm{a}$ & $15^{\mathrm{b}}$ \\
Average & $51^{\mathrm{a}}$ & $11^{\mathrm{b}}$ \\
\hline
\end{tabular}

${ }^{1}$ Primarily Setaria leucopila and Muhlenbergia porteri.

tality on both rangelands likely occurred during the period of below average precipitation in 1994-1996 (Table 2). During the summer of 1997 when above average rainfall occurred, most black grama plants on the lightly grazed rangeland showed green tops, but those on the moderately grazed rangeland remained black. Very few studies have evaluated perennial grass survival under different grazing intensities. In the Edwards Plateau of Texas, perennial grass survival during the 1950's drought was closely related to stocking rate (Young 1956). Lightly stocked pastures had $66 \%$ higher grass survival than those heavily stocked and 33\% higher than those moderately stocked. Better photosynthetic capability and more extensive root systems of lightly grazed plants under stress are the primary explanations for this relationship. An additional explanation is better soil moisture conditions under light grazing due to more mulch and soil organic matter (Molinar et al. 2001).

Dropseed mortality was over $70 \%$ on both rangelands (Table 4). Other studies have shown that black grama is more drought resistant than dropseeds (Paulsen and Ares 1962, Wright and Van Dyne 1976, Herbel and Gibbens 1996). This may be explained by black grama having a more extensive root system and more capability to extract moisture from dry soils than dropseeds.

Forage utilization during the 13 year study period averaged $26 \%$ on the lightly grazed rangeland and $49 \%$ on the moderately grazed rangeland. Generally forage use levels in excess of $50 \%$ are considered heavy based on a review by Holechek et al. (1999). Heavy grazing is defined as a degree of herbage use that does not permit desirable forage species to maintain themselves (Klipple and Bement 1961). Grazing reached the heavy level only in the summer of 1995 on the lightly grazed rangeland, but was heavy to severe for 5 consecutive years (spring 1995 to spring 1999) on the moderately grazed rangeland. Black grama stubble height averaged 11.3 $\mathrm{cm}$ on the lightly grazed rangeland, but 5.6 $\mathrm{cm}$ on the moderately grazed rangeland during the 13 year study period. A minimum stubble height of $7.6 \mathrm{~cm}$ is recommended for maintenance of black grama (Valentine 1970). Dropseed stubble heights averaged $22.5 \mathrm{~cm}$ on the lightly grazed rangeland, but $11.2 \mathrm{~cm}$ on the moderately grazed rangeland. A minimum stubble height of $15.0 \mathrm{~cm}$ is recommended for dropseeds (Holechek and Galt 2000).

Our study is consistent with earlier studies by Canfield (1939), Paulsen and Ares (1962), and Valentine (1970) that light to conservative grazing intensities can be effective in maintaining and increasing forage production on Chihuahuan Desert rangelands dominated by black grama. Our study is also consistent with these studies in showing that heavy to severe grazing during drought can quickly degrade these rangelands. Our research shows the commonly used guideline of take half and leave half does not work well on arid and semi-arid rangelands. The problem with this guideline is that major destocking will be required in $50 \%$ of the years to avoid excessive use of primary grasses (Hutchings and Stewart 1953, Paulsen and Ares 1962, Martin 1975, Galt et al. 2000). In contrast, major destocking is only needed in about 2 years out of 10 when rangelands are stocked lightly. The difficulties of estimating forage production and buying and selling livestock make management for $50 \%$ grazing use a risky and unsound proposition. Improvements in forage production and rangeland health are unlikely and the probabilities of rangeland degradation and financial ruin are high unless the rancher is extremely savvy and capable of reacting quickly.

\section{Summary and Conclusions}

Our 13 year study (1988-2000) showed an upward vegetation trend on a lightly grazed rangeland while a downward trend occurred on an adjacent moderately grazed rangeland (Fig. 1). Various measures of vegetation change were used to monitor trend in our study.

Even though forage use was estimated to average $49 \%$ on the moderately grazed rangeland during the 13 year study period, a sharp downward trend occurred. The rancher attempted to keep livestock numbers in balance with forage supplies, but was unsuccessful in 5 of the 13 years studied. Although sharp reductions were made in cattle numbers during drought years, heavy to severe grazing use still occurred. By the last 3 years of study, palatable perennial grasses had been nearly eliminated (Fig. 1). Both brush control and seeding may be needed to obtain meaningful increases in forage production on this rangeland.

In contrast to the moderately grazed rangeland, the lightly grazed rangeland had a strong upward trend in ecological condition. This was primarily due to an increase in production of black grama during the last 3 years of study. Major adjustments in cattle numbers on the lightly grazed rangeland were only needed in 1994 and 1995 when it was completely destocked due to drought and lack of forage.

Our research indicates that severe grazing during drought greatly increases perennial grass mortality compared to light grazing. Rangeland retrogression in 
the Chihuahuan Desert can occur within 2 years when drought and severe grazing are coupled together. On the other hand, recovery from short-term drought can occur within 3 years if rangelands are destocked before excessive use occurs. Light to conservative grazing is important in non-drought years because it allows black grama to increase crown area and root growth (Canfield 1939, Paulsen and Ares 1962, Valentine 1970, Young 1980). Our study supports the recommendation by various researchers that grazing intensities on Chihuahuan Desert rangelands be kept at around 30 to $35 \%$ use of perennial grasses (Canfield 1939, Paulsen and Ares 1962, Valentine 1970, Young 1980, Holechek et al. 1994).

Our data show that a combination of information on precipitation, forage production, grazing intensity, livestock numbers, range condition, and range trend are needed for sound management decisions. We recognize that it is seldom possible to collect all this information due to limitations of money, labor, time, and technology. Light to conservative grazing is most needed where intensive monitoring is not possible or practical. This minimizes the risk of destructive grazing in drought years from failure to adequately destock. Recently, several range professionals have advocated the use of a $25 \%$ harvest coefficient in arid and semi-arid areas when stocking rates are set to reduce risk and facilitate range improvement (Lacey et al. 1994, Johnston et al. 1996, White and McGinty 1997, Ward 1999, Galt et al. 2000). Our research on Chihuahuan Desert rangelands supports this recommendation.

As a final point, we believe our study contradicts Donahue's (1999) viewpoint that livestock grazing is not sustainable on arid lands receiving less than $30 \mathrm{~cm}$ of annual precipitation. During the 13 year study period, the lightly grazed pasture improved from late seral to climax ecological condition.

\section{Literature Cited}

Anderson, E. W. and W. F. Currier. 1973. Evaluating zones of utilization. J. Range Manage. 26:87-91.

Beck, R. F. 1978. A grazing system for semiarid lands. Proc. Internat. Rangeland Congr. 1:569-672.

Brown, A. L. 1950. Shrub invasion of southern Arizona desert grasslands. J. Range Manage. 3:172-177.

Buffington, L. C. and C. H. Herbel. 1965. Vegetation changes on semi-desert grassland range from 1858 to 1963. Ecol. Monogr. 35:139-164.
Campbell, R. S. 1929. Vegetation succession in the Prosopis sand dunes of southern New Mexico. Ecol. 10:392-398.

Canfield, R. H. 1939. The effect of intensity and frequency of clipping on density and yield of black grama and tobosa grass. U.S. Dept. Agr. Tech. Bull. 681.

Canfield, R. H. 1941. Application of the line intercept method in sampling range vegetation. J. Forest. 39:388-394.

Dick-Peddie, W. A. 1966. Changing vegetation patterns in southern New Mexico, p. 234 -235 . In: $16^{\text {th }}$ Field Conf. New Mexico Geol. Soc. Albuquerque, N.M.

Donahue, D. L. 1999. The western range revisited: Removing livestock from public lands to conserve biodiversity. Univ. Oklahoma Press, Norman, Okla.

Dyksterhuis, E. J. 1949. Condition and management of rangeland based on quantitative ecology. J. Range Manage. 2:104-115.

Galt, D., F. Molinar, J. Navarro, J. Joseph, and J. L. Holechek. 2000. Grazing capacity and stocking rate. Rangelands 22(6):7-11.

Herbel, C. H. and R. P. Gibbens. 1996. Postdrought vegetation dynamics on arid rangelands in southern New Mexico. New Mexico Agr. Exp. Sta. Bull. 726.

Herbel, C. H., W.L. Gould, W.F. Liefiste and R.P. Gibbens. 1983. Herbicide treatment and vegetation response to treatment of mesquite in southern New Mexico. J. Range Manage. 36:149-151.

Holechek, J. L. 1991. Chihuahuan desert rangeland, livestock grazing, and sustainability. Rangelands 13(3):115-120.

Holechek, J. L. 1992. Financial benefits of range management practices in the Chihuahuan desert. Rangelands 14(5):279-284.

Holechek, J. L. and D. Galt. 2000. Grazing intensity guidelines. Rangelands 22 (3):11-14.

Holechek, J. L. and T. Stephenson. 1983. Comparison of big sagebrush in northcentral New Mexico under moderately grazing and grazing excluded conditions. J. Range Manage. 36:455-456.

Holechek, J. L., H. Gomez, F. Molinar, and D. Galt. 1999. Grazing studies: What we've learned. Rangelands 20 (2):12-16.

Holechek, J. L., A. Tembo, A. Daniel, M. Fusco, and M. Cardenas. 1994. Long term grazing influences on Chihuahuan Desert Rangeland. Southw. Nat. 39:342-349.

Hutchings, S. S. and G. Stewart. 1953. Increasing forage yields and sheep production on intermountain winter ranges, U.S. Dept. Agr. Circ. 925.

Johnston, P. W., G. M. McKean, and K. S. Daily. 1996. Objective 'safe' grazing capacities for southwest Queensland Australia. Aust. Rangeland J. 18:244-258.

Klipple, G. E. and R. E. Bement. 1961. Light grazing - Is it economically feasible as a range improvement practice? J. Range Manage. 14:57-62.

Lacey, J., E. Williams, J. Rolleri, and M. Marlow. 1994. A guide for planning, analyzing, and balancing forage supplies with livestock demand. Montana State Univ. Ext. Publ. EB-101.
Littell, R. C., G. A. Milliken, W. W. Stroup, and R. B. Woulfinger. 1996. SAS system for mixed models. SAS Inst., Cary, N.C.

Martin, S.C. 1975. Stocking strategies and net cattle sales on semi-desert range. U.S. Dept. Agr. For. Serv. Res. Pap. RM-146.

McDaniel, K. C., L.A. Torell, and J.W. Bain. 1993. Overstory - understory relationships for broom snakeweed - blue grama rangelands. J. Range Manage. 46:506-511.

Molinar, F., D. Galt, and J. Holechek. 2001. Managing for mulch. Rangelands 23(4):3-7.

Paulsen, H. A. and F. N. Ares. 1962. Grazing values and management of black grama and tobosa grasslands and associated shrub ranges of the southwest. U.S. Dep. Agr. Tech. Bull. 1270.

Pieper, R. D. and C. H. Herbel. 1982. Herbage dynamics and primary productivity of a desert grassland ecosystem. New Mexico Agr. Exp. Stat. Bull. 695.

Pieper, R. D. and K. C. McDaniel. 1990. Ecology and management of broom snakeweed. New Mexico State Univ. Agr. Exp. Sta. Bull. 751.

Steel, R. G. and J. H. Torrie. 1980. Principles and procedures of statistics, $2^{\text {nd }}$ Edition. McGraw-Hill Book Co., New York.

Tembo, A. 1990. Influence of watering points and range condition on vegetation of the Chihuahuan Desert. Ph.D. Diss., New Mexico State Univ., Las Cruces, N.M.

United States Department of Interior Bureau of Land Management. 2000. Interpreting indicators of rangeland health. Tech. Ref. 1733-6.

Valentine, K. A. 1970. Influence of grazing intensity on improvement of deteriorated black grama range. New Mexico Agr. Exp. Sta. Bull. 553.

Ward, N. 1999. Ranchers need support for sustainable ranching: What government can do: A rancher's perspective. Rangelands 21(3):13-17.

Westoby, M. B., B. Walker, and I. Noy-Meir. 1989. Opportunistic management for rangelands not at equilibrium. J. Range Manage. 42:266-274.

White, L. D. and A. McGinty. 1997. Stocking rate decisions. Texas A\&M Univ. Agr. Ext. Serv. Publ. 13-5036.

Wright, R. G. and G. M. Van Dyne. 1976. Environmental factors influencing semidesert grassland perennial grass demography. Southw. Nat. 21:259-274.

Young, S. A. 1980. Phenological development and impact of season and intensity of defotiation of Sporobolus flexuosus and Bouteloua eriopoda. Ph.D. Diss., New Mexico State Univ., Las Cruces, N.M.

Young, V. A. 1956. The effect of the 1949-1954 drought on the ranges of Texas. J. Range Manage. 9:139-142. 